\title{
Antimycins $A_{10} \sim A_{16}$, Seven New Antimycin Antibiotics Produced by Streptomyces spp. SPA-10191 and SPA-8893
}

\author{
Nobuo Hosotani, Kazuo Kumagai, Hiroyuki Nakagawa, Takuro Shimatani, Ikutaro Saji
}

Received: April 13, 2005 / Accepted: July 7, 2005

(C) Japan Antibiotics Research Association

\begin{abstract}
Seven new antimycin antibiotics, named antimycins $\mathrm{A}_{10}, \mathrm{~A}_{11}, \mathrm{~A}_{12}, \mathrm{~A}_{13}, \mathrm{~A}_{14}, \mathrm{~A}_{15}$ and $\mathrm{A}_{16}$, were isolated from the fermentation broth of strains of Streptomyces spp. SPA-10191 and SPA-8893, along with known antimycins $\mathrm{A}_{1}, \mathrm{~A}_{2}, \mathrm{~A}_{3}$ and $\mathrm{A}_{4}$. The structures of the new antimycins were determined by spectral analyses, including 2D NMR techniques. These compounds exhibited antifungal activity against Candida utilis.
\end{abstract}

Keywords antimycin, antifungal activity, new antibiotic, Streptomyces

\section{Introduction}

Antimycins are antifungal antibiotics composed of acyl and alkyl side chains and a nine-membered dilactone ring that is linked via amide bond to 3-formamidosalicylic acid. They were first isolated from a Streptomyces strain in 1949 [1]. The isolation of antimycins $A_{1}$ to $A_{9}$ have been reported so far, and each of antimycins $A_{1} \sim A_{8}$ is a mixture of two isomers containing a closely related alkylacyl group [1 3], whereas recently reported antimycin $A_{9}$ is an aromatic acyl analogue [4] (Fig. 1). Antimycins are known to inhibit specifically the electron transfer activity of ubiquinol-cytochrome $c$ oxidoreductase [5]. Another function of antimycins reported is that they directly inhibit the activity of Bcl-2-related proteins, especially Bcl- $\mathrm{x}_{\mathrm{L}}$, which is an important regulator of cell death and survival
[6].

In our screening for biologically active compounds from microbial sources, two strains of Streptomyces spp. SPA10191 and SPA-8893 were found to produce new antimycin antibiotics, named antimycins $\mathrm{A}_{10}, \mathrm{~A}_{11}, \mathrm{~A}_{12}, \mathrm{~A}_{13}, \mathrm{~A}_{14}, \mathrm{~A}_{15}$ and $A_{16}(1 \sim 7)$, together with known antimycins $A_{1}, A_{2}, A_{3}$ and $\mathrm{A}_{4}$. In this paper we report the taxonomy of the producing strains, fermentation, isolation, structure elucidation, and antifungal activity of $\mathbf{1} \sim 7$.

\section{Materials and Methods}

\section{General}

UV spectra were recorded on a Hitachi U-2000 spectrophotometer. IR spectra were recorded on a PerkinElmer 1600 series FT-IR spectrometer. Optical rotations were measured on a Perkin-Elmer Model 241 polarimeter in a $10 \mathrm{~cm}$ cell. FAB-MS spectra were obtained on a JEOL JMS-SX102A spectrometer. NMR spectra were recorded on a JEOL JNM $\alpha-500$ spectrometer and the chemical shifts are given in ppm referred to $\mathrm{CDCl}_{3}$ as $7.25 \mathrm{ppm}\left({ }^{1} \mathrm{H}\right)$ and $77.0 \mathrm{ppm}\left({ }^{13} \mathrm{C}\right)$.

\section{Microorganism}

The producing strains SPA-10191 and SPA-8893 were isolated from soil samples collected in Kyoto and Osaka prefectures, Japan, respectively. Both strains have been deposited at the International Patent Organism Depositary,
N. Hosotani (Corresponding author), K. Kumagai, T. Shimatani, I. Saji: Exploratory Research Group, Research Division, Sumitomo Pharmaceuticals Co., Ltd., 4-2-1 Takatsukasa, Takarazuka, Hyogo 665-0051, Japan, E-mail: hosotani@sumitomopharm.co.jp
H. Nakagawa: Genomic Science Laboratories, Research Division, Sumitomo Pharmaceuticals Co., Ltd., 4-2-1 Takatsukasa, Takarazuka, Hyogo 665-0051, Japan 


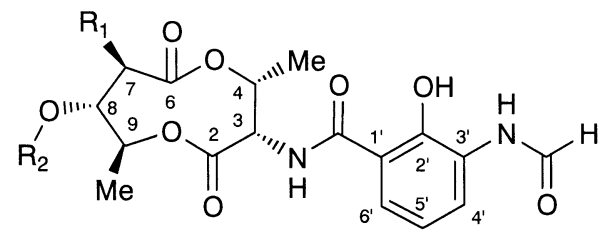

$\begin{array}{llllll} & & M W & R_{1} & R_{2} \text { (component a) } & R_{2} \text { (component b) } \\ \text { Antimycin } A_{10 a b} & \text { (1) } & 562 & \text { 4-Methylhexyl } & \text { 2-Methylbutyryl } & \text { Isovaleryl } \\ \text { Antimycin } A_{11} & (2) & 534 & \text { Butyl } & \text { Isohexanoyl } & \\ \text { Antimycin } A_{12} & (3) & 548 & \text { Isopentyl } & \text { Isohexanoyl } & \\ \text { Antimycin } A_{13} & (4) & 548 & \text { Butyl } & \text { 4-Methylhexanoyl } & \\ \text { Antimycin } A_{14} & (5) & 562 & \text { Isopentyl } & \text { 4-Methylhexanoyl } & \\ \text { Antimycin } A_{15} & (6) & 562 & \text { Hexyl } & \text { Isohexanoyl } & \\ \text { Antimycin } A_{16} & (7) & 576 & \text { Hexyl } & \text { 4-Methylhexanoyl } & \\ \text { Antimycin } A_{1 a b} & & 548 & \text { Hexyl } & \text { 2-Methylbutyryl } & \text { Isovaleryl } \\ \text { Antimycin } A_{2 a b} & 534 & \text { Hexyl } & \text { Isobutyryl } & \text { Butyryl } \\ \text { Antimycin } A_{3 a b} & 520 & \text { Butyl } & \text { 2-Methylbutyryl } & \text { Isovaleryl } \\ \text { Antimycin } A_{4 a b} & 506 & \text { Butyl } & \text { Isobutyryl } & \text { Butyryl } \\ \text { Antimycin } A_{5 a b} & 492 & \text { Ethyl } & \text { 2-Methylbutyryl } & \text { Isovaleryl } \\ \text { Antimycin } A_{6 a b} & 478 & \text { Ethyl } & \text { Isobutyryl } & \text { Butyryl } \\ \text { Antimycin } A_{7 a b} & 520 & \text { Isopentyl } & \text { Isobutyryl } & \text { Butyryl } \\ \text { Antimycin } A_{8 a b} & 534 & \text { Isopentyl } & \text { 2-Methylbutyryl } & \text { Isovaleryl } \\ \text { Antimycin } A_{9} & 554 & \text { Butyl } & \text { Phenylacetyl } & \end{array}$

Fig. 1 Structures of antimycins $A_{10}(\mathbf{1}), A_{11}(\mathbf{2}), A_{12}(\mathbf{3}), A_{13}(\mathbf{4}), A_{14}(\mathbf{5}), A_{15}(\mathbf{6}), A_{16}(\mathbf{7})$ and known antimycins $A_{1} \sim A_{9}$.

the National Institute of Advanced Industrial Science and Technology, Japan under the accession numbers FERM P-19028 and FERM P-19027, respectively.

\section{Taxonomy}

Taxonomic studies of the strains SPA-10191 and SPA-8893 were performed according to the method of Shirling and Gottlieb [7] after growing on various agar media at $27^{\circ} \mathrm{C}$ for 14 days. Fine morphological structures were observed using a Hitachi S-800 scanning electron microscope. Color names were determined by using the Color Tone Manual [8]. Cell wall analysis was performed by the method of Staneck and Roberts [9].

\section{Fermentation}

A slant culture of each strain was inoculated into a 500-ml Sakaguchi flask containing $75 \mathrm{ml}$ of liquid medium composed of glucose $2 \%$, dextrin $2 \%$, soybean flour $1.5 \%$, yeast extract $0.3 \%,\left(\mathrm{NH}_{4}\right)_{2} \mathrm{SO}_{4} 0.2 \%, \mathrm{CaCO}_{3} 0.2 \%, \mathrm{pH} 7.0$, and cultured for 4 days at $27^{\circ} \mathrm{C}$ with reciprocal shaking at $130 \mathrm{rpm}$. A volume of $6 \mathrm{ml}$ of the seed culture was transferred into 2-liter Sakaguchi flasks containing $300 \mathrm{ml}$ of the same medium, and cultured at $27^{\circ} \mathrm{C}$ with reciprocal shaking at $115 \mathrm{rpm}$. The cultivation time of the strains SPA10191 and SPA-8893 was 8 and 6 days, respectively.

\section{Antifungal Assay}

The antifungal activity was measured by the paper-disk method with Candida utilis NBRC10707. Test compounds were absorbed by paper disks ( $6 \mathrm{~mm}$ diameter) and placed on the assay plates. The fungus was cultivated in Sabouraud's agar at $30^{\circ} \mathrm{C}$. After incubation for 48 hours, zones of inhibition ( $\mathrm{mm}$ in diameter) were recorded. Antimycin $\mathrm{A}_{3}$ (Calbiochem) was used as a positive control.

\section{Results}

\section{Taxonomy}

Strains SPA-10191 and SPA-8893 formed well-branched substrate mycelia without fragmentation on agar media. Aerial mycelia were abundant on yeast extract-malt extract, oatmeal and inorganic salts - starch agar, but scant on glycerol - asparagine agar for both strains (Table 1). The color of aerial mycelium of the strain SPA-10191 was yellow, and that of reverse side of colony was reddish or grayish yellow. The spore chains were Rectiflexibiles and consisted of more than 50 spores per chain (Fig. 2a). The spore was oval and $0.5 \sim 0.6 \times 0.8 \sim 1.0 \mu \mathrm{m}$ in size with a smooth surface. In the case of the strain SPA-8893, the color of aerial mycelium was gray, and that of reverse side of colony was grayish yellow. The spore chains were Retinaculiaperti and consisted of $20 \sim 50$ spores per chain (Fig. 2b). The spore was oval and $0.6 \sim 0.8 \times 0.9 \sim 1.2 \mu \mathrm{m}$ in size with a hairy surface. The physiological characteristics and carbohydrate utilization of both strains are summerized 
Table 1 Cultural characteristic of strains SPA-10191 and SPA-8893

\begin{tabular}{crll}
\hline \multicolumn{1}{c}{ Medium } & & SPA-10191 & SPA-8893 \\
\hline \multirow{2}{*}{ Yeast extract - malt extract agar (ISP No.2) } & G: & Good & Good \\
& AM: & Good, yellow & Good, gray \\
& RS: & Reddish yellow & Grayish yellow \\
& SP: & None & None \\
& G: & Good & Good \\
& AM: & Good, yellow & Good, gray \\
& RS: & Reddish yellow & Grayish yellow \\
& SP: & None & None \\
Inorganic salts - starch agar (ISP No.4) & G: & Good & Good \\
& AM: & Good, yellow & Good, gray \\
& RS: & Reddish yellow & Grayish yellow \\
& SP: & None & None \\
& G: & Good & Good \\
& AM: & Scant, yellow & Scant, gray \\
& RS: & Grayish yellow & Grayish yellow \\
& SP: & None & None
\end{tabular}

Abbreviation. G: growth, AM: aerial mycelium, RS: reverse side color, SP: soluble pigment.

a) Strain SPA-10191

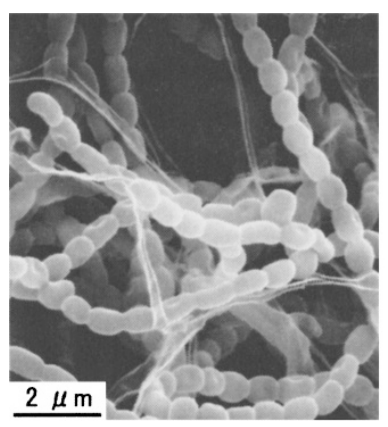

Fig. 2 Scanning electron micrograph of strains SPA10191 and SPA-8893 grown on ISP medium No. 3 at $27^{\circ} \mathrm{C}$ for 14 days.

in Table 2. The whole-cell hydrolysates of both strains contained LL-diaminopimelic acid. From the above characteristics, the strains SPA-10191 and SPA-8893 were identified as members of the genus Streptomyces, and named Streptomyces spp. SPA-10191 and SPA-8893.

\section{Isolation}

The fermentation broth (3 liters) of strain SPA-10191 was centrifuged at $9,000 \mathrm{~g}$ for 10 minutes at $20^{\circ} \mathrm{C}$. The cell cake was extracted with 2 liters of acetone and concentrated under reduced pressure to yield $1.5 \mathrm{~g}$ of oily material. The material was dissolved in $30 \mathrm{ml}$ of ethyl acetate - methanol $(50: 50)$ and applied to a silica gel column, and the column
Table 2 Physiological characteristic of strains SPA-10191 and SPA-8893

\begin{tabular}{lcc}
\hline Characteristic & SPA-10191 & SPA-8893 \\
\hline Production of melanoid pigment & & \\
Peptone - yeast extract - iron agar & - & - \\
(ISP No. 6) & & \\
Tyrosine agar (ISP No.7) & - & - \\
Carbohydrate utilization & & + \\
L-Arabinose & + & + \\
D-Fructose & + & + \\
D-Glucose & + & + \\
Inositol & \pm & + \\
D-Mannitol & + & - \\
Raffinose & \pm & - \\
L-Rhamnose & + & + \\
Sucrose & \pm & \\
D-Xylose & \pm & + \\
\hline
\end{tabular}

was eluted with the same solvent. The fractions containing antimycins $(0.6 \mathrm{~g})$ were applied to a column of Toyopearl HW-40F (Tosoh) and eluted with methanol. The fractions containing antimycins $(0.16 \mathrm{~g})$ were pooled and injected into preparative HPLC equipped with Wakopak WakosilII5C18HG-Prep columns $(30 \times 100+30 \times 250 \mathrm{~mm})$. The elution was performed with $1 \%$ aqueous formic acid methanol (20:80 to $0: 100$ in 130 minutes) at a flow rate of 
Table 3 Physico-chemical properties of $\mathbf{1} \sim \mathbf{4}$

\begin{tabular}{|c|c|c|c|c|}
\hline & 1 & 2 & 3 & 4 \\
\hline Appearance & Pale yellow solid & Pale yellow solid & Pale yellow solid & Pale yellow solid \\
\hline Molecular formula & $\mathrm{C}_{29} \mathrm{H}_{42} \mathrm{~N}_{2} \mathrm{O}_{9}$ & $\mathrm{C}_{27} \mathrm{H}_{38} \mathrm{~N}_{2} \mathrm{O}_{9}$ & $\mathrm{C}_{28} \mathrm{H}_{40} \mathrm{~N}_{2} \mathrm{O}_{9}$ & $\mathrm{C}_{28} \mathrm{H}_{40} \mathrm{~N}_{2} \mathrm{O}_{9}$ \\
\hline FAB-MS $(m / z)$ & $563(\mathrm{M}+\mathrm{H})^{+}$ & $535(\mathrm{M}+\mathrm{H})^{+}$ & $549(\mathrm{M}+\mathrm{H})^{+}$ & $549(\mathrm{M}+\mathrm{H})^{+}$ \\
\hline \multicolumn{5}{|l|}{ HRFAB-MS $(\mathrm{m} / \mathrm{z})$} \\
\hline Found: & $563.2952(\mathrm{M}+\mathrm{H})^{+}$ & $535.2661(\mathrm{M}+\mathrm{H})^{+}$ & $571.2601(\mathrm{M}+\mathrm{Na})^{+}$ & $571.2599(\mathrm{M}+\mathrm{Na})^{+}$ \\
\hline Calcd.: & 563.2969 & 535.2656 & 571.2631 & 571.2631 \\
\hline $\begin{array}{l}\text { UV } \lambda_{\max } \mathrm{nm} \\
\qquad(\varepsilon, \mathrm{MeOH})\end{array}$ & $\begin{array}{l}228(26,800), \\
321(5,000)\end{array}$ & $\begin{array}{l}228(28,700) \\
322(5,000)\end{array}$ & $\begin{array}{l}228(28,500), \\
321(4,900)\end{array}$ & $\begin{array}{l}228(26,800), \\
321(4,700)\end{array}$ \\
\hline $\mathrm{IR} v_{\max }(\mathrm{KBr}) \mathrm{cm}^{-1}$ & $\begin{array}{l}3355,2960,1743 \\
1684,1643,1529 \\
1361,1142\end{array}$ & $\begin{array}{l}3340,2958,1733 \\
1689,1635,1533 \\
1369,1151\end{array}$ & $\begin{array}{l}3342,2956,1739 \\
1685,1637,1529 \\
1365,1147\end{array}$ & $\begin{array}{l}3342,2958,1733 \\
1685,1635,1525 \\
1375,1149\end{array}$ \\
\hline$[\alpha]_{D}^{25}(\mathrm{MeOH})$ & $+88.5(c 0.03)$ & +96.7 (c 0.03$)$ & +72.2 (c 0.18$)$ & +73.3 (c 0.17$)$ \\
\hline \multicolumn{5}{|l|}{ Solubility } \\
\hline Soluble: & $\mathrm{CHCl}_{3}, \mathrm{MeOH}$ & $\mathrm{CHCl}_{3}, \mathrm{MeOH}$ & $\mathrm{CHCl}_{3}, \mathrm{MeOH}$ & $\mathrm{CHCl}_{3}, \mathrm{MeOH}$ \\
\hline Insoluble: & $\mathrm{H}_{2} \mathrm{O}, n$-Hexane & $\mathrm{H}_{2} \mathrm{O}, n$-Hexane & $\mathrm{H}_{2} \mathrm{O}, n$-Hexane & $\mathrm{H}_{2} \mathrm{O}, n$-Hexane \\
\hline
\end{tabular}

Table 4 Physico-chemical properties of $\mathbf{5} \sim \mathbf{7}$

\begin{tabular}{|c|c|c|c|}
\hline & 5 & 6 & 7 \\
\hline Appearance & Pale yellow solid & Pale yellow solid & Pale yellow solid \\
\hline Molecular formula & $\mathrm{C}_{29} \mathrm{H}_{42} \mathrm{~N}_{2} \mathrm{O}_{9}$ & $\mathrm{C}_{29} \mathrm{H}_{42} \mathrm{~N}_{2} \mathrm{O}_{9}$ & $\mathrm{C}_{30} \mathrm{H}_{44} \mathrm{~N}_{2} \mathrm{O}_{9}$ \\
\hline FAB-MS $(m / z)$ & $563(\mathrm{M}+\mathrm{H})^{+}$ & $563(\mathrm{M}+\mathrm{H})^{+}$ & $577(\mathrm{M}+\mathrm{H})^{+}$ \\
\hline \multicolumn{4}{|l|}{ HRFAB-MS $(m / z)$} \\
\hline Found: & $563.2989(\mathrm{M}+\mathrm{H})^{+}$ & $563.2972(\mathrm{M}+\mathrm{H})^{+}$ & $577.3154(\mathrm{M}+\mathrm{H})^{+}$ \\
\hline Calcd.: & 563.2969 & 563.2969 & 577.3125 \\
\hline UV $\lambda_{\max } \mathrm{nm}(\varepsilon, \mathrm{MeOH})$ & $\begin{array}{l}228(28,100) \\
321(4,900)\end{array}$ & $\begin{array}{l}228(27,400) \\
321(4,800)\end{array}$ & $\begin{array}{l}228(29,100) \\
321(5,100)\end{array}$ \\
\hline $\mathrm{IR} v_{\max }(\mathrm{KBr}) \mathrm{cm}^{-1}$ & $\begin{array}{l}3338,2958,1736 \\
1684,1637,1529 \\
1367,1149\end{array}$ & $\begin{array}{l}3336,2956,1736 \\
1684,1637,1533 \\
1367,1151\end{array}$ & $\begin{array}{l}3340,2958,1736, \\
1684,1637,1527, \\
1375,1149\end{array}$ \\
\hline$[\alpha]_{D}^{25}(\mathrm{MeOH})$ & $+75.0(c 0.07)$ & $+76.7(c 0.15)$ & $+78.8(c 0.08)$ \\
\hline \multicolumn{4}{|l|}{ Solubility } \\
\hline Soluble: & $\mathrm{CHCl}_{3}, \mathrm{MeOH}$ & $\mathrm{CHCl}_{3}, \mathrm{MeOH}$ & $\mathrm{CHCl}_{3}, \mathrm{MeOH}$ \\
\hline Insoluble: & $\mathrm{H}_{2} \mathrm{O}, n$-Hexane & $\mathrm{H}_{2} \mathrm{O}, n$-Hexane & $\mathrm{H}_{2} \mathrm{O}, n$-Hexane \\
\hline
\end{tabular}

$20 \mathrm{ml} /$ minute and detection of UV absorption at $240 \mathrm{~nm}$. Antimycins $\mathrm{A}_{4}(4.3 \mathrm{mg}), \mathrm{A}_{3}(1.7 \mathrm{mg}), \mathrm{A}_{2}(2.0 \mathrm{mg})$ and $\mathrm{A}_{1}$ $(1.7 \mathrm{mg})$ and compound $\mathbf{1}(1.3 \mathrm{mg})$ were eluted at 36.0 , 44.0, 48.0, 58.0 and 64.0 minutes, respectively.

Isolation procedures for $\mathbf{2} \sim \mathbf{7}$ from the fermentation broth (3 liters) of strain SPA-8893 were the same as described above for $\mathbf{1}$. Compounds $\mathbf{2}$ (3.5 mg), 3 (9.0 mg), 4 ( $8.6 \mathrm{mg}), \mathbf{5}(6.0 \mathrm{mg}), \mathbf{6}(7.8 \mathrm{mg})$ and $7(5.2 \mathrm{mg})$ were eluted at 47.0, 53.5, 56.6, 63.8, 67.3 and 76.1 minutes, respectively, in the final HPLC purification, together with antimycins $A_{1}(13.0 \mathrm{mg}), A_{2}(5.0 \mathrm{mg}), A_{3}(6.5 \mathrm{mg})$ and $A_{4}$ (2.6 mg).

\section{Structure Elucidation}

The physico-chemical properties of $\mathbf{1} \sim \mathbf{7}$ are summarized in Tables 3 and 4. Their UV and IR spectra showed almost the same absorption spectra respectively, and the UV spectrum ( $\lambda_{\max } 228$ and $321 \mathrm{~nm}$ in 1) and IR absorption bands ( $v_{\max }$ 1643, 1684 and $1743 \mathrm{~cm}^{-1}$ for amide and ester in 1) suggested that they were very similar to those of other 
Table $5{ }^{1} \mathrm{H}$ and ${ }^{13} \mathrm{C}$ NMR chemical shifts of $\mathbf{1}$ in $\mathrm{CDCl}_{3}$

\begin{tabular}{|c|c|c|c|c|c|}
\hline No. & ${ }^{13} \mathrm{C}$ & ${ }^{1} \mathrm{H}(J=\mathrm{Hz})$ & No. & ${ }^{13} \mathrm{C}$ & ${ }^{1} \mathrm{H}(\mathrm{J}=\mathrm{Hz})$ \\
\hline 2 & 170.07 & & $1^{\prime \prime}$ & 28.64 & $1.66(\mathrm{~m}), 1.23(\mathrm{~m})$ \\
\hline 3 & 53.67 & $5.27(t, 7.6)$ & $2^{\prime \prime}$ & 24.46 & $1.23(\mathrm{~m})$ \\
\hline 4 & 70.91 & $5.72(q, 7.0)$ & $3^{\prime \prime}$ & 36.09 & $1.23(\mathrm{~m})$ \\
\hline 6 & 172.93 & & $4^{\prime \prime}$ & 34.03 & $1.23(\mathrm{~m})$ \\
\hline 7 & 50.12 & $2.52(\mathrm{~m})$ & $5^{\prime \prime \prime}$ & 29.46 & $1.23(\mathrm{~m})$ \\
\hline 8 & 75.29 & $5.08(t, 9.7)$ & $6^{\prime \prime}$ & 11.37 & $0.81(t, 6.4)$ \\
\hline 9 & 74.90 & $4.98(\mathrm{~m})$ & $7 "$ & 18.99 & $0.80(d, 5.8)$ \\
\hline 4-Me & 14.97 & $1.30(d, 6.7)$ & Component a & & \\
\hline 9-Me & 17.85 & $1.27(d, 6.4)$ & $1^{\prime \prime \prime}$ & 175.19 & \\
\hline $1^{\prime}$ & 112.54 & & $2^{\prime \prime \prime}$ & 41.26 & $2.40(\mathrm{~m})$ \\
\hline $2^{\prime}$ & 150.64 & & $3^{\prime \prime \prime}$ & 26.46 & $1.71(\mathrm{~m}), 1.48(\mathrm{~m})$ \\
\hline $3^{\prime}$ & 127.41 & & $4^{\prime \prime \prime}$ & 11.71 & $0.93(t, 7.3)$ \\
\hline $4^{\prime}$ & 124.84 & $8.53(d, 7.9)$ & $5^{\prime \prime \prime}$ & 16.74 & $1.17(d, 6.4)$ \\
\hline $5^{\prime}$ & 119.00 & $6.91(t, 7.8)$ & Component b & & \\
\hline $6^{\prime}$ & 120.09 & $7.22(d, 8.1)$ & $1^{\prime \prime \prime}$ & 171.44 & \\
\hline $1^{\prime}-\underline{C O N H}$ & 169.39 & & $2^{\prime \prime \prime}$ & 43.23 & $2.24(d, 6.7)$ \\
\hline $1^{\prime}-\mathrm{CON} \underline{\mathrm{H}}$ & & $7.05(d, 6.4)$ & $3^{\prime \prime \prime}$ & 25.48 & $2.13(\mathrm{~m})$ \\
\hline $2^{\prime}-\mathrm{OH}$ & & $12.60(\mathrm{~s})$ & $4^{\prime \prime \prime}$ & 22.42 & $0.97(d, 6.4)$ \\
\hline 3'-N $\underline{\mathrm{H}} \mathrm{CHO}$ & & $7.92(\mathrm{br} \mathrm{s})$ & $5^{\prime \prime \prime}$ & 22.42 & $0.97(d, 6.4)$ \\
\hline 3'-NHCHO & 159.08 & $8.49(\mathrm{~s})$ & & & \\
\hline
\end{tabular}

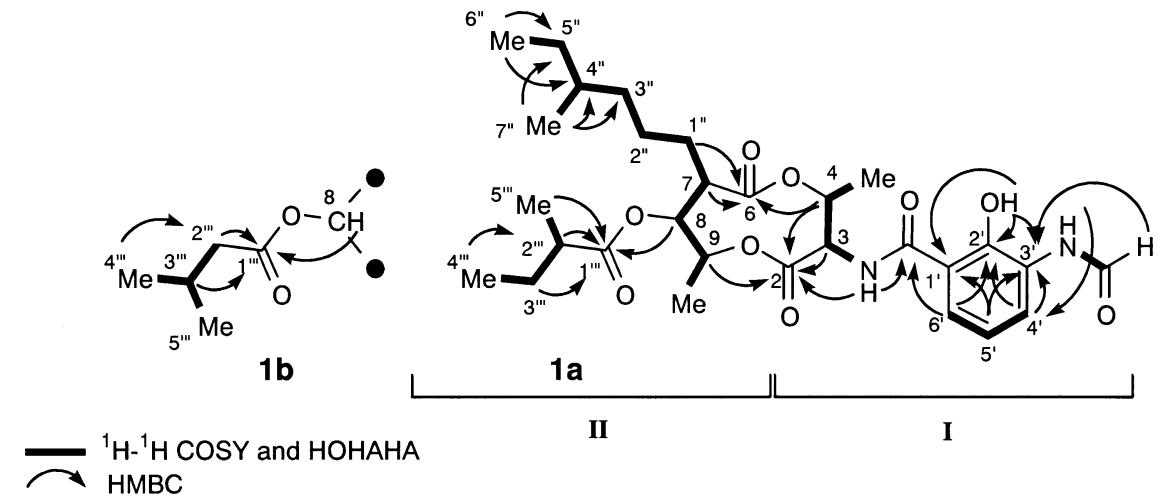

Fig. $3{ }^{1} \mathrm{H}-{ }^{1} \mathrm{H}$ COSY, $\mathrm{HOHAHA}$ and $\mathrm{HMBC}$ correlations observed in $\mathbf{1 a}$ and $\mathbf{1 b}$.

antimycin antibiotics. The molecular formula of $\mathbf{1}$ established by HRFAB-MS as $\mathrm{C}_{29} \mathrm{H}_{42} \mathrm{~N}_{2} \mathrm{O}_{9}$ was different from those of any known antimycins. The ${ }^{1} \mathrm{H}$ and ${ }^{13} \mathrm{C} \mathrm{NMR}$ spectral data of $\mathbf{1}$ are summarized in Table 5. The NMR data of 1 revealed a mixture of two related compounds $\mathbf{1 a}$ and $\mathbf{1 b}$, differing in the presence of 2-methylbutyryl or isovaleryl groups in a ratio of $85: 15$. These mixtures were inseparable by HPLC purification. Analysis of the COSY, HOHAHA and HMBC spectra of $\mathbf{1}$ revealed two partial structures I and II (Fig. 3). The partial structure I, which was assigned on the basis of ${ }^{1} \mathrm{H}$ and ${ }^{13} \mathrm{C}$ chemical shifts and the HMBC correlations, was the same as those observed for known antimycins. The partial structure II was identified through the HOHAHA spin network observed from the methyl groups $\left(\mathrm{H}_{3}-6^{\prime \prime}, \mathrm{H}_{3}-7^{\prime \prime}, \mathrm{H}_{3}-4^{\prime \prime \prime}\right.$ and $\left.\mathrm{H}_{3}-5^{\prime \prime \prime}\right)$ and $\mathrm{HMBC}$ correlations of $\mathrm{H}-7$ and $\mathrm{H}_{2}-1^{\prime \prime}$ with $\mathrm{C}-6$ and of $\mathrm{H}-8, \mathrm{H}-2^{\prime \prime \prime}$, $\mathrm{H}_{2}-3^{\prime \prime \prime}$ and $\mathrm{H}_{3}-5^{\prime \prime \prime}$ with $\mathrm{C}-1^{\prime \prime \prime}$ in $\mathbf{1 a}$ and of $\mathrm{H}-8, \mathrm{H}_{2}-2^{\prime \prime \prime}$ and $\mathrm{H}-$ $3^{\prime \prime \prime}$ with $\mathrm{C}-1^{\prime \prime \prime}$ in $\mathbf{1 b}$. These data indicated that the 7-alkyl side chain is 4-methylhexyl group and the 8-O-acyl group is 2-methylbutyryl group in $\mathbf{1 a}$ and isovaleryl group in $\mathbf{1 b}$. The HMBC correlations of H-4 with C-6 and of H-9 with C-2 revealed the connection of I with II to the formation of 
Table $6{ }^{13} \mathrm{C}$ NMR chemical shifts of $\mathbf{2} \sim \mathbf{7}$ in $\mathrm{CDCl}_{3}$

\begin{tabular}{|c|c|c|c|c|c|c|}
\hline No. & 2 & 3 & 4 & 5 & 6 & 7 \\
\hline 2 & 169.37 & 169.81 & 169.81 & 169.81 & 169.81 & 170.08 \\
\hline 3 & 53.67 & 53.73 & 53.71 & 53.73 & 53.73 & 53.66 \\
\hline 4 & 70.93 & 70.96 & 70.93 & 70.97 & 70.93 & 70.91 \\
\hline 6 & 172.94 & 172.64 & 172.66 & 172.65 & 172.66 & 172.94 \\
\hline 7 & 50.11 & 50.38 & 50.17 & 50.39 & 50.21 & 50.14 \\
\hline 8 & 75.45 & 75.49 & 75.41 & 75.50 & 75.46 & 75.44 \\
\hline 9 & 74.88 & 74.88 & 74.86 & 74.88 & 74.88 & 74.88 \\
\hline 4-Me & 14.98 & 15.15 & 15.16 & 15.16 & 15.16 & 14.97 \\
\hline 9-Me & 17.83 & 18.01 & 17.99 & 18.01 & 18.01 & 17.83 \\
\hline $1^{\prime}$ & 112.58 & 112.46 & 112.42 & 112.45 & 112.45 & 112.58 \\
\hline $2^{\prime}$ & 150.63 & 150.42 & 150.39 & 150.42 & 150.42 & 150.62 \\
\hline $3^{\prime}$ & 127.42 & 127.27 & 127.26 & 127.27 & 127.27 & 127.42 \\
\hline $4^{\prime}$ & 124.82 & 124.68 & 124.65 & 124.68 & 124.68 & 124.82 \\
\hline $5^{\prime}$ & 118.98 & 118.86 & 118.84 & 118.86 & 118.86 & 118.97 \\
\hline $6^{\prime}$ & 120.14 & 119.99 & 119.97 & 119.97 & 119.98 & 120.13 \\
\hline $1^{\prime}-\mathrm{CONH}$ & 169.37 & 169.10 & 169.07 & 169.11 & 169.10 & 169.36 \\
\hline $3^{\prime}-\mathrm{NHCHO}$ & 159.08 & 158.81 & 158.83 & 158.77 & 158.81 & 159.08 \\
\hline $1^{\prime \prime}$ & 28.14 & 26.47 & 28.28 & 26.51 & 28.56 & 28.45 \\
\hline $2^{\prime \prime}$ & 22.41 & 36.19 & 22.56 & 36.19 & 22.64 & 22.47 \\
\hline $3^{\prime \prime}$ & 29.20 & 27.96 & 29.33 & 27.97 & 27.16 & 27.03 \\
\hline $4^{\prime \prime}$ & 13.76 & 22.76 & 13.96 & 22.81 & 31.60 & 31.46 \\
\hline $5^{\prime \prime}$ & & 22.69 & & 22.71 & 29.08 & 29.08 \\
\hline $6^{\prime \prime}$ & & & & & 14.07 & 13.98 \\
\hline $1^{\prime \prime \prime}$ & 172.60 & 172.32 & 172.42 & 172.38 & 172.31 & 172.67 \\
\hline $2^{\prime \prime \prime}$ & 32.25 & 32.40 & 32.12 & 32.16 & 32.39 & 32.01 \\
\hline $3^{\prime \prime \prime}$ & 33.68 & 33.87 & 31.58 & 31.65 & 33.80 & 31.46 \\
\hline $4^{\prime \prime \prime}$ & 27.62 & 27.77 & 34.06 & 34.08 & 27.77 & 33.95 \\
\hline $5^{\prime \prime \prime}$ & 22.14 & 22.28 & 29.21 & 29.22 & 22.31 & 28.95 \\
\hline $6^{\prime \prime \prime}$ & 22.14 & 22.28 & 11.42 & 11.40 & 22.31 & 11.21 \\
\hline $7^{\prime \prime \prime}$ & & & 18.88 & 18.89 & & 18.72 \\
\hline
\end{tabular}

the 9-membered dilactone. Taken together, the structure of 1 was determined to be a mixture of two related compounds 1a and 1b, and both are new 7-alkyl side chain analogues of antimycins as shown in Fig. 1.

Compound 2 had the molecular formula $\mathrm{C}_{27} \mathrm{H}_{38} \mathrm{~N}_{2} \mathrm{O}_{9}$, as established by HRFAB-MS. The ${ }^{1} \mathrm{H}$ and ${ }^{13} \mathrm{C}$ NMR spectral data of 2 7 are summarized in Tables 6 and 7. On the basis of the ${ }^{1} \mathrm{H}$ and ${ }^{13} \mathrm{C}$ NMR spectra, 2 was different from 1a by one methyl and one methine group. Analysis of the COSY, HOHAHA and HMBC revealed that the 4-methylhexyl and 2-methylbutyryl groups in 1a were replaced with butyl and isohexanoyl groups in $\mathbf{2}$, respectively. The molecular formula of 3 and $\mathbf{4}$ were established as $\mathrm{C}_{28} \mathrm{H}_{40} \mathrm{~N}_{2} \mathrm{O}_{9}$ by HRFAB-MS, differing from that of $\mathbf{2}$ by the addition of a $\mathrm{CH}_{2}$ unit. Comparison of the NMR spectra with $\mathbf{2}$ revealed that the 7-alkyl side chain was replaced with the isopentyl group in 3 and the 8-O-acyl group was replaced with the 4- methylhexanoyl group in 4. The structures of compounds of 5 7 were determined in a similar manner to those of 2 4. The structures of 5 and 7 differed from $\mathbf{4}$ only at the 7-alkyl side chain, which were replaced with isopentyl (5) and hexyl (7) groups. The structure of $\mathbf{6}$ differed from $\mathbf{3}$ only at the 7-alkyl side chain as shown in Fig. 1. These results indicated that compounds $\mathbf{2} \sim \mathbf{7}$ are new 8-O-acyl analogues of antimycins.

The optical rotations of $\mathbf{1} \sim \mathbf{7}$ are similar to those of known antimycins. The ${ }^{1} \mathrm{H}$ and ${ }^{13} \mathrm{C}$ chemical shifts of the 9membered dilactone moiety in $\mathbf{1} \sim \mathbf{7}$ are almost identical to known antimycins. From these results, since known antimycins $A_{1}, A_{2}, A_{3}$ and $A_{4}$ were isolated from the same fermentation broth, $1 \sim 7$ are considered to possess the same 9-membered dilactone configuration as known antimycins. 
Table $7{ }^{1} \mathrm{H}$ NMR chemical shifts of $\mathbf{2} \sim \mathbf{7}$ in $\mathrm{CDCl}_{3}$

\begin{tabular}{|c|c|c|c|c|c|c|}
\hline No. & 2 & 3 & 4 & 5 & 6 & 7 \\
\hline 3 & $5.28(t, 7.6)$ & $5.30(t, 7.5)$ & $5.30(t, 7.6)$ & $5.28(t, 7.6)$ & $5.27(t, 7.6)$ & $5.27(t, 7.6)$ \\
\hline 4 & $5.72(q, 7.0)$ & $5.74(q, 7.3)$ & $5.74(q, 7.1)$ & $5.72(q, 7.1)$ & $5.72(q, 7.0)$ & $5.72(q, 7.0)$ \\
\hline 7 & $2.50(\mathrm{~m})$ & $2.51(\mathrm{~m})$ & $2.52(\mathrm{~m})$ & $2.50(\mathrm{~m})$ & $2.52(\mathrm{~m})$ & $2.52(\mathrm{~m})$ \\
\hline 8 & $5.07(t, 10.1)$ & $5.07(t, 10.0)$ & $5.07(t, 9.9)$ & $5.08(t, 9.9)$ & $5.07(t, 9.8)$ & $5.07(t, 9.8)$ \\
\hline 9 & $4.97(\mathrm{~m})$ & $5.00(\mathrm{~m})$ & $4.99(\mathrm{~m})$ & $4.99(\mathrm{~m})$ & $4.96(\mathrm{~m})$ & $4.96(\mathrm{~m})$ \\
\hline 4-Me & $1.29(d, 6.7)$ & $1.30(d, 6.7)$ & $1.30(d, 6.7)$ & $1.30(d, 6.7)$ & $1.30(d, 6.7)$ & $1.30(d, 6.7)$ \\
\hline 9-Me & $1.27(d, 6.4)$ & $1.27(\mathrm{~d}, 6.4)$ & $1.27(d, 6.4)$ & $1.27(d, 6.4)$ & $1.27(d, 6.4)$ & $1.27(d, 6.4)$ \\
\hline $4^{\prime}$ & $8.52(d, 7.4)$ & $8.54(d, 7.7)$ & $8.54(d, 7.1)$ & $8.53(d, 7.1)$ & $8.52(d, 7.9)$ & $8.52(d, 7.9)$ \\
\hline $5^{\prime}$ & $6.90(t, 7.9)$ & $6.92(t, 8.0)$ & $6.92(t, 8.1)$ & $6.90(t, 8.1)$ & $6.89(t, 8.1)$ & $6.89(t, 8.1)$ \\
\hline $6^{\prime}$ & $7.23(\mathrm{~d}, 7.7)$ & $7.24(\mathrm{~d}, 8.0)$ & $7.24(d, 7.1)$ & $7.23(d, 7.1)$ & $7.23(d, 8.0)$ & $7.23(d, 8.0)$ \\
\hline $1^{\prime}-\mathrm{CONH}$ & $7.07(d, 7.7)$ & $7.08(d, 7.5)$ & $7.08(d, 7.6)$ & $7.06(d, 7.6)$ & $7.07(d, 7.7)$ & $7.07(d, 7.7)$ \\
\hline $2^{\prime}-\mathrm{OH}$ & 12.59 (s) & 12.62 (s) & 12.62 (s) & 12.61 (s) & 12.59 (s) & 12.59 (s) \\
\hline $3^{\prime}-\mathrm{N} \underline{\mathrm{HCHO}}$ & 7.97 (br s) & 7.97 (br s) & 7.99 (br s) & 7.93 (br s) & 7.98 (br s) & 7.98 (br s) \\
\hline 3'-NHC트O & $8.49(\mathrm{~s})$ & 8.51 (s) & 8.51 (s) & $8.49(\mathrm{~s})$ & $8.49(\mathrm{~s})$ & $8.49(\mathrm{~s})$ \\
\hline $1^{\prime \prime}$ & $\begin{array}{l}1.67(\mathrm{~m}) \\
1.23(\mathrm{~m})\end{array}$ & $\begin{array}{l}1.66(\mathrm{~m}) \\
1.37(\mathrm{~m})\end{array}$ & $\begin{array}{l}1.68(\mathrm{~m}) \\
1.23(\mathrm{~m})\end{array}$ & $\begin{array}{l}1.66(\mathrm{~m}) \\
1.37(\mathrm{~m})\end{array}$ & $\begin{array}{l}1.69(\mathrm{~m}) \\
1.23(\mathrm{~m})\end{array}$ & $\begin{array}{l}1.69(\mathrm{~m}) \\
1.23(\mathrm{~m})\end{array}$ \\
\hline $2^{\prime \prime}$ & $1.23(\mathrm{~m})$ & $1.25(\mathrm{~m})$ & $1.23(\mathrm{~m})$ & $1.15(\mathrm{~m})$ & $1.23(\mathrm{~m})$ & $1.23(\mathrm{~m})$ \\
\hline $3^{\prime \prime}$ & $1.23(\mathrm{~m})$ & $1.48(\mathrm{~m})$ & $1.23(\mathrm{~m})$ & $1.46(\mathrm{~m})$ & $1.23(\mathrm{~m})$ & $1.23(\mathrm{~m})$ \\
\hline $4^{\prime \prime}$ & $0.85(t, 7.0)$ & $0.83(d, 6.7)$ & $0.85(t, 7.1)$ & $0.83(d, 6.7)$ & $1.23(\mathrm{~m})$ & $1.23(\mathrm{~m})$ \\
\hline $5^{\prime \prime}$ & & $0.83(d, 6.7)$ & & $0.83(d, 6.7)$ & $1.23(\mathrm{~m})$ & $1.23(\mathrm{~m})$ \\
\hline $6^{\prime \prime}$ & & & & & $0.87(t, 7.1)$ & $0.86(t, 7.1)$ \\
\hline $2^{\prime \prime \prime}$ & $2.34(t, 7.5)$ & $2.37(t, 7.5)$ & $2.36(\mathrm{~m})$ & $2.36(\mathrm{~m})$ & $2.34(\mathrm{~m})$ & $2.34(\mathrm{~m})$ \\
\hline $3^{\prime \prime \prime}$ & $1.52(\mathrm{~m})$ & $1.52(\mathrm{~m})$ & $\begin{array}{l}1.64(\mathrm{~m}) \\
1.47(\mathrm{~m})\end{array}$ & $\begin{array}{l}1.64(\mathrm{~m}) \\
1.46(\mathrm{~m})\end{array}$ & $1.55(\mathrm{~m})$ & $\begin{array}{l}1.64(\mathrm{~m}) \\
1.45(\mathrm{~m})\end{array}$ \\
\hline $4^{\prime \prime \prime}$ & $1.56(\mathrm{~m})$ & $1.56(\mathrm{~m})$ & $1.30(\mathrm{~m})$ & $1.38(\mathrm{~m})$ & $1.56(\mathrm{~m})$ & $1.30(\mathrm{~m})$ \\
\hline $5^{\prime \prime \prime}$ & $0.90(d, 6.5)$ & $0.90(d, 6.5)$ & $1.23(\mathrm{~m})$ & $1.28(\mathrm{~m})$ & $0.92(d, 6.4)$ & $1.23(\mathrm{~m})$ \\
\hline $6^{\prime \prime \prime}$ & $0.90(d, 6.5)$ & $0.90(d, 6.5)$ & $0.87(t, 7.0)$ & $0.87(t, 7.0)$ & $0.92(d, 6.4)$ & $0.87(t, 7.0)$ \\
\hline $7^{\prime \prime \prime}$ & & & $0.86(d, 6.2)$ & $0.86(d, 6.2)$ & & $0.86(d, 6.2)$ \\
\hline
\end{tabular}

\section{Antifungal Activity}

Compounds 1 $\sim 7$ were evaluated for antifungal activity against Candida utilis using a paper-disk assay. The diameter of inhibition zone of $\mathbf{1} \sim \mathbf{6}$ were 8.0 9.0 and $10.0 \sim 12.0 \mathrm{~mm}$ at 0.02 and $0.2 \mu \mathrm{g} / \mathrm{disk}$, respectively (Table 8 ). Compound 7 weakly inhibited the growth and the diameter of inhibition zone was 7.0 and $8.0 \mathrm{~mm}$ at 0.02 and $0.2 \mu \mathrm{g} /$ disk, respectively, whereas that of antimycin $\mathrm{A}_{3}$ as a positive control was 12.0 and $15.0 \mathrm{~mm}$ at 0.02 and $0.2 \mu \mathrm{g} /$ disk, respectively.

\section{Discussion}

We have isolated seven new antimycin antibiotics 1 7 from the fermentation broths of two Streptomyces sp. strains. Compound $\mathbf{1}$ is a mixture of two isomers containing 2-methylbutyryl and isovaleryl groups, as shown in antimycins $A_{1}, A_{3}, A_{5}$, and $A_{8}$ (Fig. 1). Compound 1 is the
Table 8 Antifungal activity of $\mathbf{1} \sim \mathbf{7}$ and antimycin $A_{3}$ against Candida utilis NBRC10707

\begin{tabular}{cccc}
\hline \multirow{2}{*}{ Antimycins } & \multicolumn{2}{c}{ Diameter of inhibitory zone $(\mathrm{mm})$} \\
\cline { 3 - 4 } & & $0.02 \mu \mathrm{g} /$ disk & $0.2 \mu \mathrm{g} /$ disk \\
\hline $\mathrm{A}_{10}$ & $(\mathbf{1})$ & 8 & 10 \\
$\mathrm{~A}_{11}$ & $(\mathbf{2})$ & 9 & 12 \\
$\mathrm{~A}_{12}$ & $(\mathbf{3})$ & 9 & 11 \\
$\mathrm{~A}_{13}$ & $(\mathbf{4})$ & 8 & 10 \\
$\mathrm{~A}_{14}$ & $(\mathbf{5})$ & 8 & 10 \\
$\mathrm{~A}_{15}$ & $(\mathbf{6})$ & 8 & 10 \\
$\mathrm{~A}_{16}$ & $(\mathbf{7})$ & 7 & 8 \\
$\mathrm{~A}_{3}{ }^{a)}$ & 12 & 15 \\
\hline
\end{tabular}

a) Positive control. 
first antimycin antibiotic containing a $\mathrm{C}_{7} 7$-alkyl side chain, and compounds $\mathbf{2} \sim \mathbf{7}$ are the first examples of antimycins containing $\mathrm{C}_{6}$ or $\mathrm{C}_{7} 8$-O-alkylacyl group. Compounds $\mathbf{1}, 4$ and $\mathbf{6}$ are closely related to antimycin $\mathrm{A}_{0}$, but the structure of the latter compound was not clearly elucidated [10]. The order of the antifungal potency was found to be antimycin $\mathrm{A}_{3}>\mathbf{2} \geqq \mathbf{3} \geqq \mathbf{1}, \mathbf{4}, \mathbf{5}, \mathbf{6}>\mathbf{7}$. This activity order suggested that there are inverse relationships between the antifungal activity and the length of the 7-alkyl and 8-O-acyl side chains.

Acknowledgement We wish to thank Mr. Tetsuya Nishide for his excellent assistance in the fermentation and isolation.

\section{References}

1. Dunshee BR, Leben C, Keitt GW, Strong FM. The isolation and properties of antimycin A. J Am Chem Soc 71: 2436-2437 (1949)

2. Barrow CJ, Oleynek JJ, Marinelli V, Sun HH, Kaplita P, Sedlock DM, Gillum AM, Chadwick CC, Cooper R. Antimycins, inhibitors of ATP-citrate lyase, from a Streptomyces sp. J Antibiot 50: 729-733 (1997)
3. Bycroft DW. Dictionary of Antibiotics and Related Substances. Chapman and Hall, London (1988)

4. Shiomi K, Hatae K, Hatano H, Matsumoto A, Takahashi Y, Jiang CL, Tomoda H, Kobayashi S, Tanaka H, S. Ōmura. A new antibiotic, antimycin A9, produced by Streptomyces sp. K01-0031. J Antibiot 58: 74-78 (2005)

5. Wikstrom MK, Berden JA. Oxidoreduction of cytochrome b in the presence of antimycin. Biochim. Biophys. Acta 283: 403-420 (1972)

6. Tzung SP, Kim KM, Basanez G, Giedt CD, Simon J, Zimmerberg J, Zhang KY, Hockenbery DM. Antimycin A mimics a cell-death-inducing Bcl-2 homology domain 3. Nat Cell Biol 3: 183-191 (2001)

7. Shirling EB, Gottlieb D. Methods for characterization of Streptomyces species. Int J Syst Bacteriol 16: 313-340 (1966)

8. Nippon Shikisai Kenkyuusyo (Ed.). Color Tone Manual. Nippon Shikiken Jigyo Co., Tokyo (1973)

9. Staneck JL, Roberts GD. Simplified approach to identification of aerobic actinomycetes by thin-layer chromatography. Appl Microbiol 28: 226-231 (1974)

10. Schilling G, Berti D, Kluepfel D. Antimycin A components. II. Identification and analysis of antimycin A fractions by pyrolysis-gas liquid chromatography. J Antibiot 23: 81-90 (1970) 